\title{
SURVEY, COLLECTION, ISOLATION AND IDENTIFICATION OF ISOLATES OF PYRICULARIA ORYZAE CAUSING RICE BLAST IN SOUTHERN KARNATAKA BY USING HOST DIFFERENTIAL LINES
}

\section{AKHILESH KUMAR KULMITRA, NEHA SAHU \& V. B. SANATH KUMAR}

Department of Plant Pathology, University of Agricultural Sciences, Bangalore

A survey was conducted during kharif 2015-16 in southern Karnataka, to assess the percent severity and incidence of rice leaf and neck blast. The freshly infected leaves were randomly collected from all the talks viz., Mandya, Maddur, Nagamangala, Shrirangapattana, Pandavapura, Krishnarajpet, and Malavalli of Mandya district of Karnataka, from these samples, the causal organism was isolated by following tissue isolation method and monoconidial isolation. Among all the talk, the highest percent disease severity of the rice leaf blast was recorded (38.92\%) in Krishnarajpet Taluk and lowest incidence was recorded (27.39\%) in Maddur Taluk. Among all the talk, the highest percent disease incidence of neck blast was recorded (20.61\%) in Shrirangapattana Taluk and lowest incidence was recorded (13.04\%) in Maddur Taluk. Screening of promising host differential lines against rice blast was carried out to identify the races of $P$. oryzae. Among twenty five host differential lines of paddy, 2, 3, 4, 10, 12, 13 and 22 host differential shows resistant reaction. Host differential lines $6,7,8,9,11,14,23,24$ and 25 show moderate resistances. Host differential lines 15, 16 and 17 exhibited susceptible reaction.

KEYWORDS: Rice Blast, Tissue Isolation, Monoconidial Isolation, Severity, Incidence \& Host Differential Lines
\end{abstract}

Received: Apr 19, 2017; Accepted: May 15, 2017; Published: May 27, 2017; Paper Id.: IJASRJUN201737

\section{INTRODUCTION}

Rice is a cereal grain, belonging to the grass family of Poaceae, and native to the deltas of the great Asian rivers, the Ganges, the Chang (Yangtze) and the Tigris and Euphrates. The rice plant grows from 2 to $6 \mathrm{ft}$ tall, with a round, jointed stem, long pointed leaves and edible seeds borne in dense heads on separate stalks. Rice is one of the most cultivated grain crops in India as well as in Asian countries, and a staple diet of the major part of India. India is an important center for rice cultivation and consumption. South India consumes more rice than any part of the country. India stands in second position after China in the production of rice. The world's estimated rice production is 496.0 million metric tons during 2016 (Anon, 2016). India is the largest rice growing country, accounting for about one third of the world acreage under the crop. In India's annual rice production is 103.6 million tons during 2016 (Anon, 2016).

Rice is a nutritional staple food, which provides instant energy as its most important component is carbohydrate (starch). On the other hand, rice is poor in nitrogenous substances with an average composition of these substances being only 8per cent and fat content or lipids only negligible, i.e. 1 per cent and due to this reason it is considered as a complete food for eating. Rice flour is rich in starch and is used for making various food materials. It is also used in some instances by brewers to make alcoholic malt. Likewise, rice straw mixed with other materials is used to produce porcelain, glass and pottery. Rice is also used in manufacturing of paper pulp 
and livestock bedding. Rice has shaped the culture, diets and economic of thousand of millions of people. For more than half of the humanity, "rice is life". Considering its important position, the United Nation designated year 2004 as the "International Year of Rice.

In south Indian region, comprises of Karnataka, Andhra Pradesh, Kerala and Tamil Nadu, Rice is mainly grown in deltaic tracts of Godavari, Krishna and Cauvery rivers and the non-deltaic rain fed area of Tamil Nadu and Andhra Pradesh. Rice is grown under irrigated condition in deltaic tracts.

\section{MATERIAL AND METHODS}

Roving survey was conducted during kharif 2015-16, around Mandya district of southern Karnataka to assess the percent severity, and incidence of rice leaf and neck blast.

\section{Collection of Infected Specimen and Isolation of the Fungus}

The freshly infected leaves were randomly collected from all the seven talks viz., Mandya, Maddur, Nagamangala, Shrirangapattana, Pandavapura, Krishnarajpet, and Malavalli of Mandya district of Karnataka, and were used for isolation by adopting the following methods.

\section{Tissue Isolation Technique}

Rice leaves with blast symptoms were first washed in tap water, and then cut into small bits of $2 \mathrm{~mm}$ size, containing the blast lesion along with a portion of healthy tissue surrounding the lesion. These bits were surface sterilized with 0.1 percent sodium hypochlorite solution for two min, followed by three changes of sterilized distilled water. These bits were transferred into petri dishes containing $15 \mathrm{ml}$ solidified PDA under aseptic conditions, and incubated at $28 \pm 1^{0} \mathrm{C}$ and watched for the growth of colony, regularly. For the growth of the pathogen from the tissue, or for any contamination, up to fourteen days investigation was done. After fourteen days of incubation, a small loop of fungal culture from the colonies was picked, and put on a clean slide containing a drop of lacto phenol. The slide was observed under low and high power objectives for the presence of pyriform conidia.

\section{Single Spore Isolation Technique (Monoconidial Isolation)}

Well developed lesions were identified, excised and washed in running tap water. The leaf bits were surface sterilized with 0.1 sodium hypochlorite for $2 \mathrm{~min}$, and then washed three times with sterile water and allow for speculation on sterilized glass slides, by incubating in a moist chamber at $28 \pm 1^{0} \mathrm{C}$ for $48 \mathrm{~h}$. Well sporulated lesions were placed in double distilled water, in the test tubes and vortexed for $1 \mathrm{~min}$. About $1 \mathrm{ml}$ of spore suspension was added to sterilize plates, and $2 \%$ agar was added. Single spore was located and picked up microscopically. Each spore was eventually transferred to solidified PDA slants. The slats were incubated at $28 \pm 1^{0} \mathrm{C}$ for 2 days and stored at $4^{0} \mathrm{C}$ for further use. (Goh, 1999)

\section{Identification of Races of Pyricularia Oryzae by using Host differentials}

The experiment was conducted during Rabi 2015-16 at Krishi Vigyan Kendra Farm, V.C. Farm, Mandya, screening of promising host differential lines, against the blast of rice caused by $P$. oryzae and its races.

Screening work was carried out by pot culture technique. The sterilized soil, sand and FYM were mixed in 1:1:0.5 proportion (w/w basis) and filled in disinfected earthen pot. Seeds were shown on pots; after 15 days, when two leafy 
Survey, Collection, Isolation and Identification of Isolates of Pyricularia Oryzae

stages were appeared the spore suspension of different isolates was inoculated. The pots were covered with polyethylene bags for 4 days, after that, the polyethylene bags were removed and then, observation was recorded based on disease scale (0-9) (Table 1) and disease grade (Table 2).

A total of 25 host differentials was sown during Rabi 2015-16, and were evaluated for the reaction of leaf blast. Each germplasm entry was shown in two rows at a distance of $30 \mathrm{~cm}$ long and $10 \mathrm{~cm}$ apart, between the two test entries, and two lines of local susceptible variety was sown after every 25 lines.

The screening of germplasm for their reaction to leaf blast was carried under greenhouse conditions. Scoring for leaf blast was done at nursery stage as per the scale given by Nagaraja et al., (2007).

Table 1: Scale for Rice Blast Caused by P. Oryzae

\begin{tabular}{|c|l|}
\hline Scale & \multicolumn{1}{|c|}{ Description } \\
\hline 0 & No infection \\
\hline 1 & Pin head spots less than 1 per cent leaf area affected \\
\hline 2 & Pin head spots 5-10 per cent leaf area affected \\
\hline 3 & Typical blast spots with grey centre 5-25 per cent leaf area affected \\
\hline 4 & 25-50 per cent leaf areas affected \\
\hline 5 & Large spots with grey centre more than 50 per cent leaf area affected \\
\hline
\end{tabular}

On the basis of disease grade obtained the germplasm were grouped into the following categories.

Table 2: Disease Grade and Varietal Reaction for Rice Blast Caused by P. Oryzae

\begin{tabular}{|l|l|}
\hline \multicolumn{1}{|c|}{ Disease Grade } & \multicolumn{1}{c|}{ Varietal Reaction } \\
\hline 0 & Immune (I) \\
\hline Up to 1 & Highly resistance (HR) \\
\hline$>1.1$ to 2.0 & Resistant (R) \\
\hline$>2.1$ to 3.0 & Moderately resistant (MR) \\
\hline$>3.1$ to 4.0 & Moderately susceptible (MS) \\
\hline$>4.1$ to 5.0 & Susceptible (S) \\
\hline$>5$ & Highly Susceptible (HS) \\
\hline
\end{tabular}

\section{RESULTS}

\section{Survey on Severity of Rice Leaf Blast (P. Oryzae $)$}

Roving survey was conducted during kharif 2015-16 around the Mandya district of Karnataka, to assess the percent severity of blast disease of rice and the results of the data is presented in table 8 , figure 1

The symptoms in the field of rice were recognized by broadly spindle shaped spots, with the pale ashy center and brownish red margins seen on the leaf. In case of severe infection, several such spots coalesce and the lamina are destroyed (Plate 1)

Average per cent severity of rice leaf blast i.e. 30.31 per cent was recorded in Mandya Taluk. Highest percent disease severity was recorded (43.27\%) in V.C. Farm village and the lowest was recorded (18.68\%) in Madla village.

Average percent disease severity of rice leaf blast i.e. 27.39 per cent was recorded in Maddur Taluk. Maximum percent disease severity was recorded $(41.88 \%)$ in Sompura and minimum was recorded (16.82\%) in Volagarahalli village.

Average percent disease severity, i.e. 33.98 per cent was recorded in Nagamangala Taluk. Maximum disease severity $(45.61 \%)$ was recorded in Shivanhalli village and the minimum was recorded $(27.36 \%)$ in Hulikere village. 
Average percent disease severity, i.e. 38.31 per cent was recorded in Shriranagapattana Taluk. Maximum disease severity was recorded (45.88\%) in Mallenhalli village and the minimum was recorded (33.50\%) in Kodalakuppe village.

Average percent disease severity, i.e. 33.48 per cent was recorded in Pandavapura Taluk. Maximum disease severity of was recorded (41.23\%) in Haranahalli village and the minimum was recorded $(26.75 \%)$ in Berankoppe village.

Average percent disease severity, i.e. 38.92 per cent was recorded in Krishnarajpet Taluk. Maximum disease severity of was recorded (46.88\%) in Laxmipura village and the minimum was recorded (31.23\%) in Hosaholalu village.

Average percent disease severity, i.e. 33.85 per cent was recorded in Malavalli Taluk. Maximum disease severity of was recorded (41.60\%) in Markalu village and the minimum was recorded (26.82\%) in Haladasanahalli village.

\section{Survey on Incidence of Rice Neck Blast (P. Oryzae)}

Roving survey was conducted during 2015-16 around the Mandya district of Karnataka, to assess the incidence of neck blast disease of rice, and the results of the data is presented in table 3, figure 1.

The symptoms in the field of rice were recognized by broadly spindle shaped spots, with the pale ashy center and brownish red margins are seen on the neck. In case of severe infection, several such spots coalesce and the lamina are destroyed (Plate 1)

The average per cent incidence of rice neck blasts i.e. 15.83 per cent in Mandya talk was. Highest per cent incidence was recorded (24.25\%) in V.C. Farm village and lowest recorded (9.68\%) in Madla village.

Average percent disease incidence, i.e. 13.04 per cent was recorded in Maddur Taluk. Maximum disease incidence was recorded $(23.23 \%)$ in Sompura and minimum disease incidence was recorded (7.62\%) in Volagarahalli village.

Average percent disease incidence, i.e. 16.73 per cent was recorded in Nagamangala Taluk. Maximum disease incidence was recorded $(22.32 \%)$ in Shivanhalli village and minimum disease incidence was recorded (11.28\%) in Hulikere village.

Average percent disease incidence, i.e. 20.61 per cent was recorded in Shriranagapattana Taluk. Maximum disease incidence was recorded (28.96\%) in Mallenhalli village and minimum disease incidence was recorded (13.72\%) in Kodalakuppe village.

Average percent disease incidence, i.e. 16.41 per cent was recorded in Pandavapura Taluk. Maximum disease incidence was recorded (21.63\%) in Haranahalli village and minimum disease incidence was recorded (10.82\%) in Berankoppe village.

Average percent disease incidence, i.e. 20.38 per cent was recorded in Krishnarajpet talk Maximum disease incidence was recorded $(29.85 \%)$ in Laxmipura village and minimum disease incidence was recorded (14.28\%) in Hosaholalu village.

Average percent disease incidence, i.e. 33.85 per cent was recorded in Malavalli Taluk Maximum disease incidence was recorded (41.60\%) in Markalu village and minimum disease incidence was recorded (26.82\%) in Haladasanahalli village.

Among all the talk surveyed (Figure 1) (Table 3) highest average percent disease severity of the rice leaf blast was 
recorded (38.92\%) in Krishnarajpet Taluk and lowest incidence was recorded $(27.39 \%)$ in Maddur Taluk. The village with highest percent disease severity was recorded (46.88\%) in Laxmipura village of Krishnarajpet Taluk and lowest per cent disease severity was recorded (16.82\%) in the Volagarahalli village of Maddur Taluk.

Among all the talk surveys (Figure 2) (Table 4) highest average percent disease incidence of neck blast was recorded $(20.61 \%)$ in Shrirangapattana Taluk and lowest incidence was recorded (13.04\%) in Maddur Taluk. The village with highest percent disease incidence was recorded $28.96 \%)$ in the Malenhalli village of Shrirangapattana Taluk and lowest per cent disease incidence was recorded (7.62\%) in the Volagarahalli village of Maddur Taluk.

Table 3: Percent Severity and Incidence of Rice Leaf and Neck Blast Disease around Mandya District

\begin{tabular}{|c|c|c|c|c|c|c|c|}
\hline & Name of Taluk & Name of Village & Varieties & $\begin{array}{c}\text { Leaf Blast } \\
(\%)\end{array}$ & $\begin{array}{c}\text { Mean } \\
(\%)\end{array}$ & $\begin{array}{c}\text { Neck Blast } \\
(\%)\end{array}$ & $\begin{array}{c}\text { Mean } \\
(\%)\end{array}$ \\
\hline \multirow{8}{*}{1.} & \multirow{8}{*}{ Mandya } & Dudda & MTU 1001 & 34.71 & \multirow{8}{*}{30.31} & 18.71 & \multirow{8}{*}{15.83} \\
\hline & & Shivalli & MTU 1001 & 35.53 & & 19.56 & \\
\hline & & Hullenahalli & MTU 1001 & 38.32 & & 17.94 & \\
\hline & & Madla & BR 2655 & 18.68 & & 9.68 & \\
\hline & & Holalu & BR 2655 & 21.40 & & 12.45 & \\
\hline & & Mallanayakanakatte & Thanu & 26.83 & & 14.85 & \\
\hline & & Gandalu & BR 2655 & 23.74 & & 9.21 & \\
\hline & & V.C.Farm & Jyoti & 43.27 & & 24.25 & \\
\hline \multirow{10}{*}{2.} & \multirow{10}{*}{ Maddur } & Desahalli & Jaya & 24.93 & \multirow{10}{*}{27.39} & 11.12 & \multirow{10}{*}{13.04} \\
\hline & & Sivapura & Jaya & 38.71 & & 14.65 & \\
\hline & & N.I.Doddi & Thanu & 28.37 & & 8.68 & \\
\hline & & Sompura & MTU 1001 & 41.88 & & 23.23 & \\
\hline & & Volagarahalli & BR 2655 & 16.82 & & 7.62 & \\
\hline & & Bellur & Jaya & 37.74 & & 18.52 & \\
\hline & & Somanhalli & BR 2655 & 19.80 & & 11.47 & \\
\hline & & Haralahalli & BR 2655 & 17.51 & & 9.58 & \\
\hline & & Shankarapura & Thanu & 28.63 & & 12.92 & \\
\hline & & Hosahalli & BR 2655 & 19.55 & & 12.68 & \\
\hline \multirow{5}{*}{3.} & \multirow{5}{*}{ Nagamangala } & Shivanhalli & Jyoti & 45.61 & \multirow{5}{*}{33.98} & 22.32 & \multirow{5}{*}{16.73} \\
\hline & & Dondemadanahalli & Jyoti & 34.95 & & 17.88 & \\
\hline & & Vaddarahalli & Jaya & 32.52 & & 19.52 & \\
\hline & & Hulikere & Thanu & 27.36 & & 11.28 & \\
\hline & & Javaranahalli & Thanu & 29.47 & & 12.65 & \\
\hline \multirow{7}{*}{4.} & \multirow{7}{*}{ Shrirangapattana } & Rampura & MTU 1001 & 43.52 & \multirow{7}{*}{38.31} & 23.56 & \multirow{7}{*}{20.61} \\
\hline & & Doddegowdan koppalu & Jaya & 39.27 & & 19.52 & \\
\hline & & Mallenhalli & MTU 1001 & 45.88 & & 28.96 & \\
\hline & & Huknalli & Thanu & 36.34 & & 20.04 & \\
\hline & & K.shettihalli & BR 2655 & 28.93 & & 13.72 & \\
\hline & & Kudalakuppe & MTU 1001 & 33.50 & & 16.39 & \\
\hline & & Naguvahalli & MTU 1001 & 40.73 & & 22.12 & \\
\hline \multirow{10}{*}{5.} & \multirow{10}{*}{ Pandavapura } & Chikkabyadarahalli & Mangala & 39.53 & \multirow{10}{*}{33.48} & 17.32 & \multirow{10}{*}{16.41} \\
\hline & & Haranahalli & MTU 1001 & 41.23 & & 21.63 & \\
\hline & & Pattasomanhalli & Thanu & 28.50 & & 14.69 & \\
\hline & & Harohalli & Jaya & 34.30 & & 16.54 & \\
\hline & & Rajmundanlli & Jaya & 32.32 & & 15.85 & \\
\hline & & Gumnalli & Jyoti & 35.29 & & 13.24 & \\
\hline & & Berankoppe & Thanu & 26.75 & & 10.82 & \\
\hline & & Vasuru & Jyoti & 33.53 & & 19.54 & \\
\hline & & Devegowdankapalu & Jyoti & 31.50 & & 15.23 & \\
\hline & & Narayanpura & Jyoti & 37.92 & & 19.28 & \\
\hline \multirow{2}{*}{6.} & \multirow{2}{*}{ Krishnarajpet } & Bommenahalli & Rajmudi & 44.52 & & 24.22 & \multirow{2}{*}{20.38} \\
\hline & & Harinahalli & Thanu & 39.27 & & 18.23 & \\
\hline
\end{tabular}




\begin{tabular}{|c|c|c|c|c|c|c|}
\hline Name of Taluk & Name of Village & Varieties & $\begin{array}{c}\text { Leaf Blast } \\
(\%)\end{array}$ & $\begin{array}{c}\text { Mean } \\
(\%)\end{array}$ & $\begin{array}{c}\text { Neck Blast } \\
(\%)\end{array}$ & $\begin{array}{c}\text { Mean } \\
(\%)\end{array}$ \\
\hline & Laxmipura & MTU1001 & 46.88 & \multirow{5}{*}{39.92} & 29.85 & \\
\hline & Ichanahalli & Rajmudi & 36.34 & & 17.56 & \\
\hline & Akkihebbala & Jaya & 33.50 & & 14.28 & \\
\hline & Hosaholalu & Jaya & 31.23 & & 16.98 & \\
\hline & Machahalli & MTU 1001 & 40.73 & & 21.58 & \\
\hline \multirow{9}{*}{ Malavalli } & Ravani & Minilong & 36.5 & \multirow{9}{*}{33.85} & 14.32 & \multirow{9}{*}{14.73} \\
\hline & Haladasanahalli & BR 2655 & 26.82 & & 9.56 & \\
\hline & Ragibommanahalli & Thanu & 32.68 & & 15.76 & \\
\hline & Markalu & Minilong & 41.60 & & 18.65 & \\
\hline & Kanhalli & Jaya & 35.52 & & 14.28 & \\
\hline & Manjunuru & Jaya & 37.32 & & 19.65 & \\
\hline & Halasahalli & Jyoti & 30.11 & & 13.38 & \\
\hline & Jarajanpura & Jaya & 33.35 & & 14.34 & \\
\hline & Akkomorkopalla & Jaya & 33.42 & & 12.68 & \\
\hline
\end{tabular}

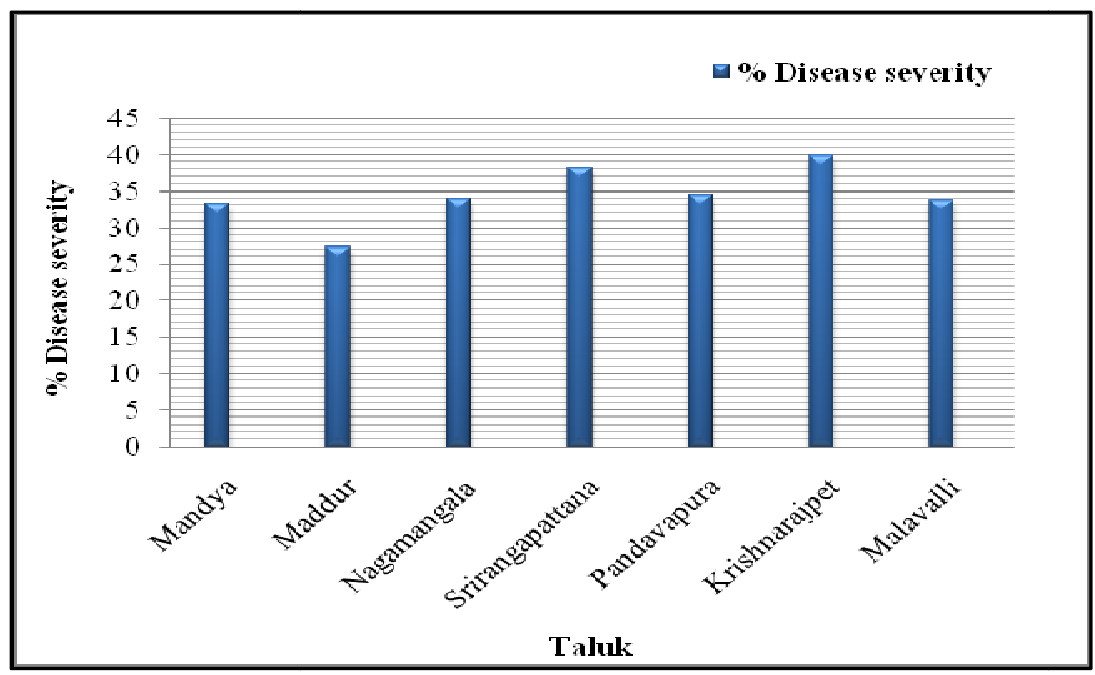

Figure 1: Per Cent Disease Severity of Rice Leaf Blast in different Taluks of Mandya District

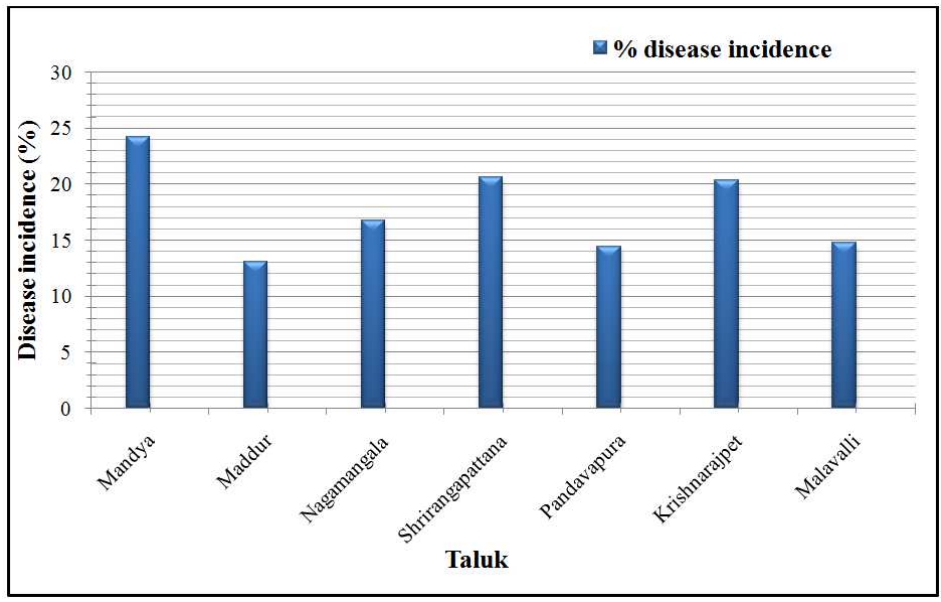

Figure 2: Per Cent Disease Incidence of Rice Neck Blast in different Taluks of Mandya District 
Survey, Collection, Isolation and Identification of Isolates of Pyricularia Oryzae Causing Rice Blast in Southern Karnataka by using Host Differential Lines
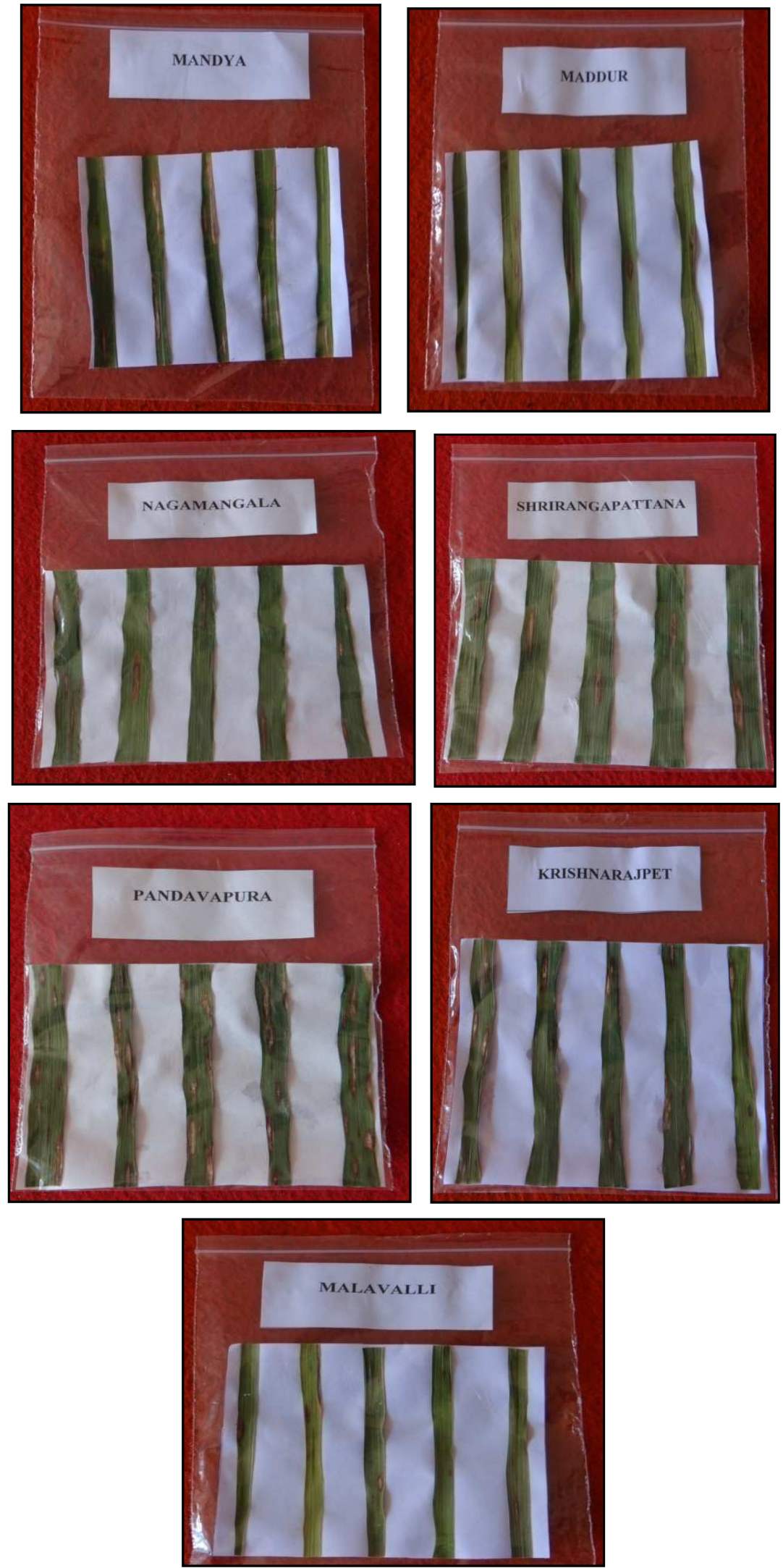

Plate 1: Typical Symptoms of All Isolates of the Rice Leaf Blast 


\section{Collection, Isolation and Identification of $P$. Oryzae}

The infected leaf samples having typical symptoms of blast on rice caused by $P$. arise were collected from all the seven talks of Mandya district (Plate 1). From these samples, the causal organism was isolated by following tissue isolation method. Further, monoconidial isolation was done to obtain pure cultures of all isolates, as detailed in 'material and methods. The fungus was sub-cultured on PDA slants, and stored in refrigerator at $4^{0} \mathrm{C}$. For further studies, the original culture of each isolates was revived once in 30 days.

\section{Identification of Races of P. Oryzae by using Host differential}

The present study was made to locate the resistant sources to $P$. Rise in rice, as the utilization of resistant varieties is a classical approach to prevent losses caused due to the disease. This approach is novel in the management of disease, as it involves no or less cost of production.

Among twenty five host differential lines of paddy, 2, 3, 4, 10, 12, 13 and 22, host differential shows resistant reaction. Host differential lines 6, 7, 8, 9, 11, 14, 23, 24 and 25 show moderate resistance. Host differential lines 15, 16 and 17 exhibited susceptible reactions (Table 6).

Table 4: Isolates of P. Oryzae

\begin{tabular}{|c|l|l|c|}
\hline SI. No. & \multicolumn{1}{|c|}{ Location } & Plant Part & Isolates Designation \\
\hline 1 & Mandya & Leaf & $\mathrm{I}_{1}$ \\
\hline 2 & Maddur & Leaf & $\mathrm{I}_{2}$ \\
\hline 3 & Nagamangala & Leaf & $\mathrm{I}_{3}$ \\
\hline 4 & Shrirangapattana & Leaf & $\mathrm{I}_{4}$ \\
\hline 5 & Pandavapura & Leaf & $\mathrm{I}_{5}$ \\
\hline 6 & Krishnarajpet & Leaf & $\mathrm{I}_{6}$ \\
\hline 7 & Malavalli & Leaf & $\mathrm{I}_{7}$ \\
\hline
\end{tabular}

Table 5: Identification of Races of P. Oryzae by using Host differential Lines of Rice during Rabi 2015-16

\begin{tabular}{|c|c|c|c|c|c|c|c|c|}
\hline \multirow{3}{*}{ Host Differential Lines } & \multicolumn{7}{|c|}{ Reaction } & \multirow{3}{*}{ No. of Isolates } \\
\hline & \multicolumn{7}{|c|}{ Isolates } & \\
\hline & I-1 & I-2 & I-3 & I-4 & I-5 & I-6 & I-7 & \\
\hline 1 & $\mathrm{~S}$ & $\mathrm{R}$ & $\mathrm{S}$ & $\mathrm{S}$ & $\mathrm{R}$ & $\mathrm{R}$ & $\mathrm{R}$ & 4 \\
\hline 2 & $\mathrm{~S}$ & $\mathrm{R}$ & $\mathrm{S}$ & $\mathrm{S}$ & $\mathrm{R}$ & $\mathrm{R}$ & $\mathrm{R}$ & 4 \\
\hline 3 & $\mathrm{~S}$ & $\mathrm{R}$ & $\mathrm{R}$ & $\mathrm{S}$ & $\mathrm{R}$ & $\mathrm{S}$ & $\mathrm{R}$ & 6 \\
\hline 4 & $\mathrm{R}$ & $\mathrm{R}$ & $\mathrm{R}$ & $\mathrm{R}$ & $\mathrm{R}$ & $\mathrm{S}$ & $\mathrm{R}$ & 6 \\
\hline 5 & $\mathrm{~S}$ & $\mathrm{R}$ & $\mathrm{R}$ & $\mathrm{R}$ & $\mathrm{R}$ & $\mathrm{R}$ & $\mathrm{R}$ & 6 \\
\hline 6 & $\mathrm{R}$ & $\mathrm{S}$ & $\mathrm{R}$ & $\mathrm{R}$ & $\mathrm{S}$ & $\mathrm{R}$ & $\mathrm{R}$ & 5 \\
\hline 7 & $\mathrm{R}$ & $\mathrm{S}$ & $\mathrm{R}$ & $\mathrm{R}$ & $\mathrm{S}$ & $\mathrm{R}$ & $\mathrm{R}$ & 5 \\
\hline 8 & $\mathrm{~S}$ & $\mathrm{R}$ & $\mathrm{R}$ & $\mathrm{R}$ & $\mathrm{R}$ & $\mathrm{R}$ & $\mathrm{S}$ & 5 \\
\hline 9 & $\mathrm{~S}$ & $\mathrm{R}$ & $\mathrm{R}$ & $\mathrm{R}$ & $\mathrm{R}$ & $\mathrm{S}$ & $\mathrm{R}$ & 5 \\
\hline 10 & $\mathrm{R}$ & $\mathrm{R}$ & $\mathrm{R}$ & $\mathrm{R}$ & $\mathrm{S}$ & $\mathrm{R}$ & $\mathrm{R}$ & 6 \\
\hline 11 & $\mathrm{R}$ & $\mathrm{S}$ & $\mathrm{R}$ & $\mathrm{R}$ & $\mathrm{S}$ & $\mathrm{R}$ & $\mathrm{R}$ & 5 \\
\hline 12 & $\mathrm{R}$ & $\mathrm{S}$ & $\mathrm{R}$ & $\mathrm{R}$ & $\mathrm{R}$ & $\mathrm{R}$ & $\mathrm{R}$ & 6 \\
\hline 13 & $\mathrm{R}$ & $\mathrm{R}$ & $\mathrm{S}$ & $\mathrm{R}$ & $\mathrm{R}$ & $\mathrm{R}$ & $\mathrm{R}$ & 6 \\
\hline 14 & $\mathrm{R}$ & $\mathrm{R}$ & $\mathrm{S}$ & $\mathrm{R}$ & $\mathrm{S}$ & $\mathrm{R}$ & $\mathrm{R}$ & 5 \\
\hline 15 & $\mathrm{~S}$ & $\mathrm{R}$ & $\mathrm{S}$ & $\mathrm{R}$ & $\mathrm{S}$ & $\mathrm{S}$ & $\mathrm{R}$ & 3 \\
\hline 16 & $\mathrm{~S}$ & $\mathrm{~S}$ & $\mathrm{R}$ & $\mathrm{R}$ & $\mathrm{R}$ & $\mathrm{S}$ & $\mathrm{S}$ & 3 \\
\hline 17 & $\mathrm{R}$ & $\mathrm{S}$ & $\mathrm{R}$ & $\mathrm{S}$ & $\mathrm{R}$ & $\mathrm{S}$ & $S$ & 3 \\
\hline 18 & $\mathrm{R}$ & $\mathrm{R}$ & $\mathrm{R}$ & $\mathrm{S}$ & $\mathrm{R}$ & $\mathrm{S}$ & $\mathrm{S}$ & 4 \\
\hline 19 & $\mathrm{~S}$ & $\mathrm{R}$ & $\mathrm{S}$ & $\mathrm{S}$ & $\mathrm{R}$ & $\mathrm{R}$ & $\mathrm{R}$ & 4 \\
\hline 20 & $\mathrm{~S}$ & $\mathrm{~S}$ & $\mathrm{~S}$ & $\mathrm{R}$ & $\mathrm{R}$ & $\mathrm{R}$ & $\mathrm{R}$ & 4 \\
\hline
\end{tabular}


Survey, Collection, Isolation and Identification of Isolates of Pyricularia Oryzae Causing Rice Blast in Southern Karnataka by using Host Differential Lines

\begin{tabular}{|c|l|l|l|l|l|l|l|c|}
\hline \multicolumn{7}{|c|}{ Table 5: Contd., } \\
\hline 21 & $\mathrm{R}$ & $\mathrm{S}$ & $\mathrm{S}$ & $\mathrm{R}$ & $\mathrm{R}$ & $\mathrm{S}$ & $\mathrm{R}$ & 4 \\
\hline $\mathbf{2 2}$ & $\mathrm{R}$ & $\mathrm{R}$ & $\mathrm{R}$ & $\mathrm{R}$ & $\mathrm{R}$ & $\mathrm{S}$ & $\mathrm{R}$ & 6 \\
\hline 23 & $\mathrm{R}$ & $\mathrm{R}$ & $\mathrm{R}$ & $\mathrm{S}$ & $\mathrm{S}$ & $\mathrm{R}$ & $\mathrm{R}$ & 5 \\
\hline 24 & $\mathrm{~S}$ & $\mathrm{R}$ & $\mathrm{R}$ & $\mathrm{S}$ & $\mathrm{S}$ & $\mathrm{R}$ & $\mathrm{R}$ & 5 \\
\hline 25 & $\mathrm{~S}$ & $\mathrm{R}$ & $\mathrm{R}$ & $\mathrm{S}$ & $\mathrm{R}$ & $\mathrm{R}$ & $\mathrm{R}$ & 5 \\
\hline
\end{tabular}

\section{$\underline{\text { Grades }} \underline{\text { Reaction }}$}

$0 \quad=$ Immune $(\mathrm{I})$,

1-2 = Highly Resistant (HR),

3-4 = Resistant $(\mathrm{R})$,

$5-6=$ Susceptible $(\mathrm{S})$

7-9 = Highly susceptible (HS)

\section{DISCUSSIONS}

\section{Survey, Isolation and Proving Pathogenicity of $P$. Oryzae}

A survey of the disease prevalence of rice blast was undertaken in seven talks of Mandya district, Karnataka viz., Mandya, Maddur, Nagamangala, Shrirangapattana, Pandavapura, Krishnarajpet and Malavalli Taluk. Infected sample showing typical blast symptoms on leaf, neck and nodal portion was collected. The culture of each location was considered as an individual isolates.

During survey, highest average per cent disease severity (38.92\%) was recorded in Krishnarajpet Taluk ( $\left.\mathrm{I}_{6}\right)$, whereas, lowest percent severity (27.39\%) was recorded in the Maddur Taluk ( $\left.\mathrm{I}_{2}\right)$. Morgan Hossain (2000) and Anwar et al., (2009) also surveyed for the percent severity of rice blast. Morgan Hossain (2000) recorded 61.66 percent disease incidence in Uttar Kannada due to blast caused by P. oryzae. However, the present study shows that the maximum disease severity (38.92\%) was recorded in Krishnarajpet Taluk $\left(\mathrm{I}_{6}\right)$. Hence, the variation in disease incidence among different talks is attributed to the varied climatic conditions and edaphic factors like soil temperature, soil moisture and soil $\mathrm{pH}$.

The sample of rice leaves affected by blast disease was collected from all the talk of Mandya district of Karnataka. The pathogen isolated from diseased leaf showing typical symptoms was identified, as $P$. oryzae on the basis of morphological characters. Pure culture was maintained in PDA medium through hyphal tip isolation technique. The isolation of rice blast fungus observed were in agreement with the description, Dhua (1986), Xia et al., (1993), Goh (1999) and Lima and Duclos (2001).

Pathogenicity test was carried out under pot culture conditions in glasses by inoculating with pathogenic culture of $P$. oryzae. Infected plant leaf showed gray at the center, has a dark border and it is spindle-shaped lesions. The symptoms of rice blast observed were in agreement with the description of Ghose et al., (1960); Pinnschmidt et al., (1994); Padmanabhan (1974) and Manibhushan Rao (1994). Hence, pathogencity tests showed typical symptoms, when inoculated with pathogenic culture of $P$. oryzae. Re-isolation of the fungus from such affected leaf tissue in variably yielded pathogenic culture of $P$. oryzae. Hence, the present study clearly indicated that $P$. arise is involved in causing blast disease in rice. 


\section{Identification of Races of $P$. Oryzae by using Host differential}

The present study was made to locate the resistant sources to $P$. Rise in rice, as the utilization of resistant varieties is a classical approach to prevent losses caused due to the disease. This approach is novel in the management of disease, as it involves no or less cost of production.

Among twenty five host differential lines of paddy, 2, 3, 4.10, 12, 13 and 22, the host differentials show resistant reaction. The host differential lines 6, 7, 8, 9, 11, 14, 23, 24 and 25 show moderate resistances. Host differential lines 15, 16 and 17 exhibited susceptible reaction.

\section{ACKNOWLEDGEMENTS}

The author wishes to thank Professor V. B. Sanath Kumar, University of Agricultural Sciences, Bangalore, for his sustained interest in this work and the preparation of this paper. The award of ICAR Junior Research fellowship to the author is also gratefully acknowledged.

\section{REFERENCES}

1. Anonymous, 2016, Statistical database. www.fao.org.

2. Anwar, A., Ali, M. A., Bhat, G. N., Parray, G. A. and Wani, M., 2009, Status of rice blast Pyricularia grisea, cultivar reaction and races of its causal fungus in temperate agro-ecosystem of Kashmir, India. SAARC J. Agric., 7(2): 25-37.

3. Dhua, V., 1986, A selective method for isolating Pyricularia from blast lesion. Curr. Sci., 55: 410-411.

4. Ghose, R. L. M., Ghatage, M. B. and Subrahmanyan, V., 1960, Disease, Rice in India, pp. 67.

5. Goh, T. K., 1999, Single spore isolation using a hand-made glass needle, Fungal Diversity. 2: 47-63.

6. Lima, A. and Duclos, J., 2001, Host, mating type and fertility of Magnoporthae grisea in Santigo Island, Cape Verde archipelago, Phytopathol. Mediterr., 40: 119-124.

7. Manibhusan Rao, K., 1994, Rice Blast Disease. 1st Ed., Daya Publishing House, Delhi, pp. 1.

8. Mijan Hossain, M. D., 2000, Studies on blast disease of rice caused by Pyricularia grisea (cooke) Sacc. In upland area. M.Sc. Thesis, Univ.Agric. Sci., Dharwad, pp. 52-53.

9. Nagaraja, A., Kumar, J., Jain, A. K., Narasimhadu, Y., Raghuchander, T., Kumar, B. and Gowda, B. H., 2007, Compendium of small millets diseases. Project Coordinator Cell, All India Coordinated Small Millets Improvement Project, UAS, GKVK Campus, Bengaluru. pp. 80.

10. Padmanabhan, S. Y., 1974, Fungal Diseases of Rice in India. 1st Ed. Indian council of Agriculture Research, New Delhi.

11. Pinnschmidt H, Teng P. and Luo, Y., 1994, Methodology for quantifying rice yield effects of blast. In: Zeigler RS, Leong SA, Teng PS, editors. Rice blast disease. Wallingford, Oxon (United Kingdom): CAB International, Los Banos (Philippines): International Rice Research Institute, pp. 381-408.

12. Xia, T. Q., Correll, J. C., Lee, F. N., Marchetti, M. A. and Rhoads, D. D., 1993, DNA finger printing to examine microgeographic variation in the M. grisea (P. grisea) population in two rice field in Arkansana. Phytopathol, 83: 1029-1035. 